\title{
Measurement Unit Description
}

National Cancer Institute

\section{Source}

National Cancer Institute. Measurement Unit Description. NCI Thesaurus. Code C92571.

An expression that conveys significant information about the type of measurement of observation. 